\title{
Influence of repeated remelting of the alloy RR.350 on structure and thermo-mechanical properties
}

Marek Břuska, Petr Lichý, Michal Cagala, Jaroslav Beňo

VŠB-TU Ostrava, FMMI, Department of metallurgy and foundry, 17. listopadu 15/2172, CZ 708 33, Ostrava-Poruba, Czech Republic, marek.bruska.st@vsb.cz

This research investigates the influence of repeated use of the Al-Cu-based alloy. In our case we used the alloy RR.350. Specimens for the tensile test were cast into a metallic mould, to which a protective coating was applied. Altogether 15 specimens were prepared from each melt in order to obtain more accurate results. During casting the temperature of metal and mould was controlled from the viewpoint of ensuring constant conditions of the experiment. Test bars were prepared from the cast specimens for measurement of tensile strength at normal $\left(20^{\circ} \mathrm{C}\right.$ ) and elevated temperatures (up to $350^{\circ} \mathrm{C}$ ). Furthermore parts were taken from the cast specimens for measurement of hardness (HB) and for metallographic analysis. Thermo-mechanical properties of the investigated alloy were determined at the working site of the authors - Department of Metallurgy and Foundry at the Faculty of Metallurgy and Materials Engineering, VŠB - Technical University of Ostrava. This experiment has unequivocally confirmed the negative effect of repeated use of the investigated alloy on its thermomechanical and structural properties.

Keywords: Tensile test, thermo-mechanical properties, metallic mould

\section{Acknowledgments}

The paper was prepared under financial support of TAČR (TA02011333 - Physical and metallurgical aspects of preparation of cast metallic foams from iron alloys and alloys of non-ferrous metals) and the project of specific research of VŠB-TU Ostrava SP2013/62 and RMSTC (Regional Materials Science and Technology Centre at the V̌̌B-TU Ostrava-CZ.1.05/2.1.00/01.0040).

\section{References}

[1] MICHNA, S., NÁPRSTKOVÁ, N. (2012). Research into the causes cracking of aluminum alloys of $\mathrm{Al}-\mathrm{Cu}$ during mechanical machining. Manufacturing Technology, Vol. 12, No. 12, pp. 47 - 51, ISSN 1213 - 2489.

[2] ROUČKA, J. (2004). Metallurgy of alloys of non-ferrous metals, Textbook, 148 pp. Akademické nakladatelství CERM, Brno, ISBN 80-214-2790-6.

[3] WEISS, V., STRIHAVKOVA, E. (2012). Influence of the homogenization annealing on microstructure and mechanical properties of AlZn5,5Mg2,5Cu1,5 alloy, Manufacturing Technology, Vol. 12, No. 13, pp. 297 - 302, ISSN 1213-2489.

[4] MICHNA, Š. et al. (2005). Aluminium encyclopaedia, 1st ed., 700 pp. Adin, Prešov. ISBN 80-89041-88-4.

[5] MICHALCOVÁ, A., VOJTĚCH, D. (2012). Structure of rapidly solidified aluminium alloys. Manufacturing Technology, Vol. 12, No. 13, pp. 166 - 169, ISSN 1213 - 2489.

[6] TillovÁ, E., CHAlupovÁ, M., HURTAlOVÁ, L., ĎURINÍKOVÁ, E. (2011). Quality control of microstructure in recycled Al-Si cast alloys, Manufacturing Technology, Vol. 11, No. 11, pp. 70 - 76, ISSN 1213 - 2489.

[7] PÍŠEK, F., JENÍČEK, L., RYŠ, P. (1973). Material science I, Metal science, Textbook, Vol. 3, Non-ferrous metals, 595 pp. Academia, Praha.

[8] Č́ǏŽEK, L. (1990). Practicum for metal testing I., Basic testing methods, Textbook, 134 pp., VŠB, Ostrava.

[9] http://aluminium.matter.org.uk [online]. 2001 [cit. 2011-01-12]. AluMATTER.

[10] KOŘENÝ, R. (1991). Possibilities of enhancement of quality of high-strength and refractory foundry aluminium alloys, Textbook, VŠB, Ostrava.

[11] BIROL, Y. (2012). Performance of AlTi5B1, AlTi3B3 and AlB3 master alloys in refining grain structure of aluminium foundry alloys. Materials Science and Technology, Vol. 28, No. 4, pp. 481-486.

[12] NAGLIĆ, I., SMOLEJ, A., DOBERŠEK, M. (2009). The influence of alloying elements in aluminium on the grain refinement with AlTi5B1. Metalurgija, Vol. 48, No. 3, pp. 147-150. 